\title{
The research of aquasorb's bibulous rate and water-retention property
}

\author{
Zewei Jiang ${ }^{1, a}$, Hongkai $\mathrm{Li}^{2, \mathrm{~b}}$
}

${ }^{1}$ College of Water Resources and Hydropower, Hohai University, Nanjing 210000, China;

${ }^{2}$ College of Water Resources and Hydropower, Hohai University, Nanjing 210000, China.

a18351961522@163.com, 'lhkk1995@163.com

Keywords: aquasorb, the bibulous rate, water-retention property, EM bacteria

\begin{abstract}
The test compares and analyses the bibulous rate of different doses of $4 \mathrm{~g}, 6 \mathrm{~g}, 8 \mathrm{~g}$ aquasorb in pure water and its water-retention property with EM bacteria in soil. The result shows : those three aquasorb all can absorb little water quickly,however, the larger the quantity, the slower the absorption rate. When absorbs $500 \mathrm{ml}$ water, the water-absorption rates of the $6 \mathrm{~g}, 8 \mathrm{~g}$ are almost the same and more than the $4 \mathrm{~g}$. They all have a certain water retention but the $6 \mathrm{~g}$ and $8 \mathrm{~g}$ aquasorb have the same ability to inhibit the evaporation while better than the $4 \mathrm{~g}$ which prove the aquasorb can absorb water effectively and play a role in water-retention.
\end{abstract}

\section{Introduction}

Nowadays, the shortage of water have already became the grand factors of impacting even restricting agriculture and economy of China with the problem of contradiction of the water resource's supply and demand in agriculture is getting more and more serious. Therefore, it is a problem has to be settled as quickly as possible that developing the dry and water saving farming.Aquasorb is a macromolecular compound which can absorb water thousands weight of itself.Besides, aquasorb can improve the water-retention property of soil,the structure of the soil ,the utilization of water and fertilizer,so it has a widely and prospecting future in terms of the agriculture production.In addition, microorganism in the EM bacteria form a complicated, stability structured, widely functioned, non-toxic effected efficient microorganisms that can improve water-retention property of soil to save water to a certain degree. The test combines aquasorb with EM bacteria in order to search the influence of the aquasorb's bibulous rate and combined action with the EM bacteria to the water-retention property of the soil, which might be a new solution of saving and retaining water.

\section{Material and methods}

\subsection{Test material}

The test was carried out in Nanjing vegetables and flowers institute in August,2014. We used yellow soil on which grew tobacco early.The fermentation test of EM bacteria rejuvenation liquid and the water absorption of aquasorb are both indoors while the evaporation test was carried out outdoors with non rain and airless weather.During the test, the average daily highest temperature is $30.1^{\circ} \mathrm{C}$, the maximum average humidity is $64 \%$, the aquasorb and EM stoste molasses are bought from The Nanjing Aimule Environmental Protection Biological LTD.

\subsection{Test design}

The application amount of the aquasorb are $0 \mathrm{~g}, 4 \mathrm{~g}, 6 \mathrm{~g}, 8 \mathrm{~g}$ per pot.The $0 \mathrm{~g}$ aquasorb is a blank control, they all have 3 repetition per treatment. Put deionized water into different doses of aquasorb to $50 \mathrm{ml}, 100 \mathrm{ml}, 150 \mathrm{ml}, 200 \mathrm{ml}, 300 \mathrm{ml}, 350 \mathrm{ml}, 400 \mathrm{ml}, 500 \mathrm{ml}$. Record the time from it starts absorbing water with a stopwatch and observe the bibulous rate's change with different doses of aquasorb. Bury the aquasorb which have absorbed water completely $2 \mathrm{~cm}$ soil layer under the flower pots uniformly.Each process in the soil surface uniformly added $30 \mathrm{ml}$ of EM bacteria.After recording weighed pots of soil quality, natural evaporation into the open space. Don't forget to shelter them from the rain. The test continued 7 days and we weighed the soil bowl at 6o'clock pm everyday. 


\section{Results and analysis}

\subsection{Bibulous rates with different doses of aquasorb}

Bibulous rate is a important index which reflects the water absorption performance.It refers to retaining agent in an aqueous solution of unit mass per unit time can absorb the equivalent of how many times their own quality, which is a key index to measure whether the aquasorb can absorb water quickly or not.[9] From the figure 1,2 and 3 we know that different doses of the water absorbent rate different curves. From figure 4,Those three doses to $50 \mathrm{ml}$ water absorbent when used fairly, $8 \mathrm{~g}$ aquasorb gradually absorbing water to $500 \mathrm{ml}$ rate slightly less than $6 \mathrm{~g}$ insurance agent.However, statistically no significant difference between the two, and each quantitative water, than $4 \mathrm{~g}$ aquasorb fast. $4 \mathrm{~g}$ to about $350 \mathrm{ml}$ water absorbent is close to saturation, $6 \mathrm{~g}, 8 \mathrm{~g}$ still saturated when the water absorbent to $500 \mathrm{ml} .4 \mathrm{~g}, 6 \mathrm{~g}, 8 \mathrm{~g}$ aquasorb $150 \mathrm{ml}$ water used in the absorption time to reach $30.82 \%$ of the time water $350 \mathrm{ml}, 41.02 \%, 38.19 \%$ respectively. Illustrate the actual application, when the environmental conditions are exactly the same, insurance agent can quickly absorb a small amount of water, the more water-retaining agent dose, the greater the absorption rate, but after absorption rate became smaller and aquasorb exceed $6 \mathrm{~g}$, the time of absorbing $500 \mathrm{ml}$ water has little differences.

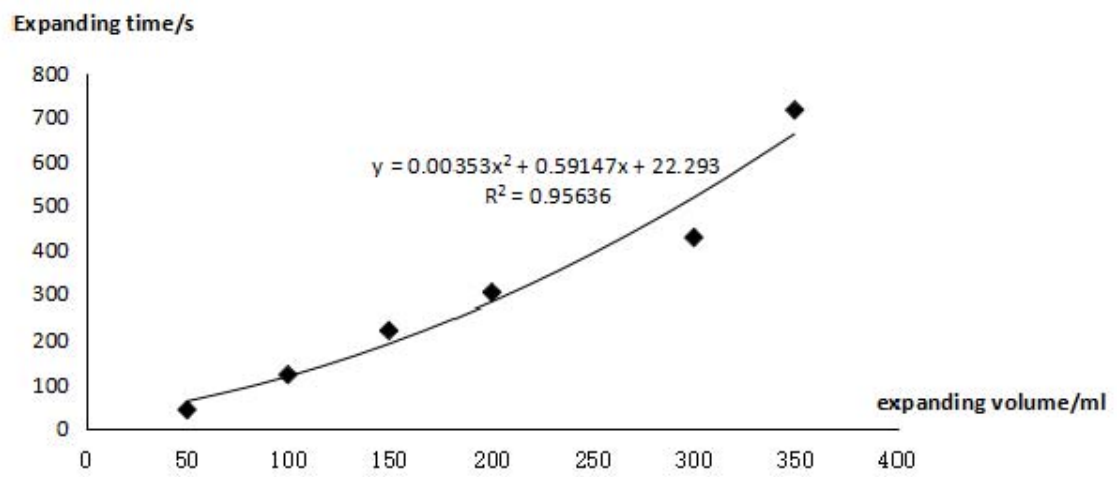

Figurel the water absorption rate of the $4 \mathrm{~g}$ aquasorb
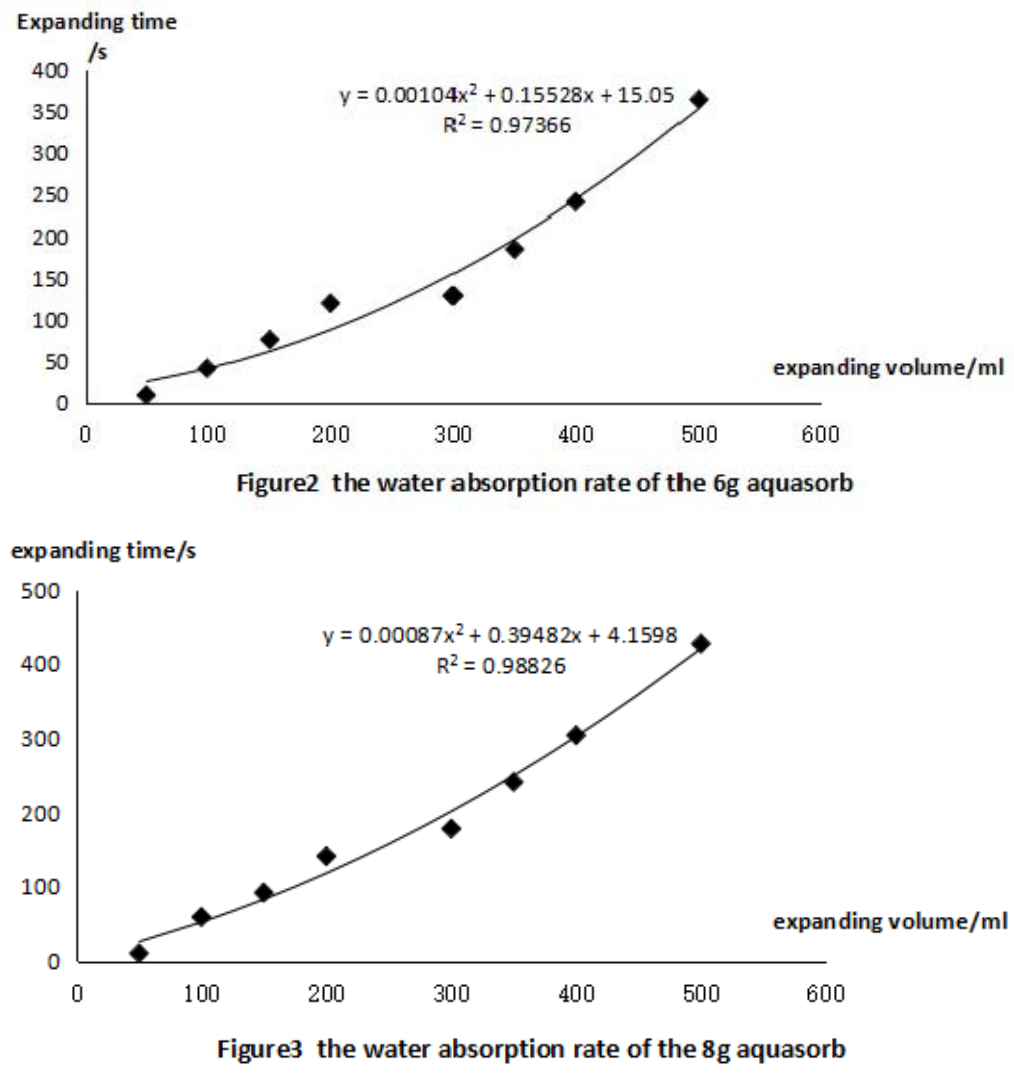


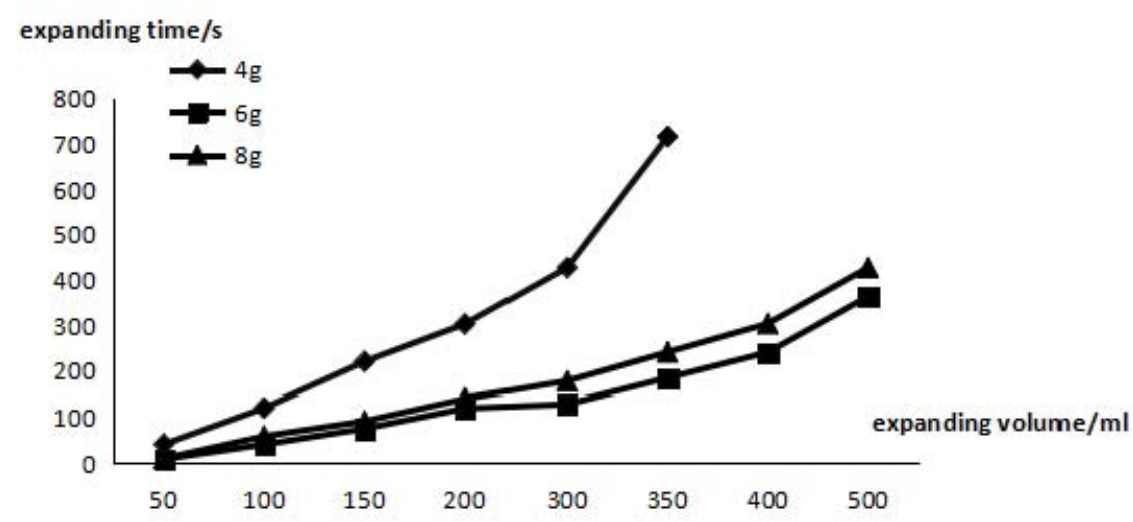

Figure4 the water absorption rate of different doses of aquasorb

\subsection{Different doses of super absorbent polymers in the soil water retention}

Aquasorb water retention refers to the expansion of the body after absorbing ability to maintain an aqueous solution without isolation is a reflection of whether the resulting solution can be fully utilized and be an important indicator of long-term application [10]. As can be seen from Figure 5, compared with the control, different doses retaining agent could to some extent, inhibit evaporation. $4 \mathrm{~g}, 6 \mathrm{~g}, 8 \mathrm{~g}$ aquasorb evaporation process accounted for $77.78 \%$ of the control, $55.56 \%, 55.56 \%$ respectively. Thus, when less than $6 \mathrm{~g}$ saturated with water or water-retaining agent to $500 \mathrm{ml}$, aquasorb the greater the dose, the better the water in the soil mediator, water retention stronger. $6 \mathrm{~g}, 8 \mathrm{~g}$ aquasorb same evaporation process, indicating that when water $500 \mathrm{ml}$, the same two doses aquasorb water retention in the soil.

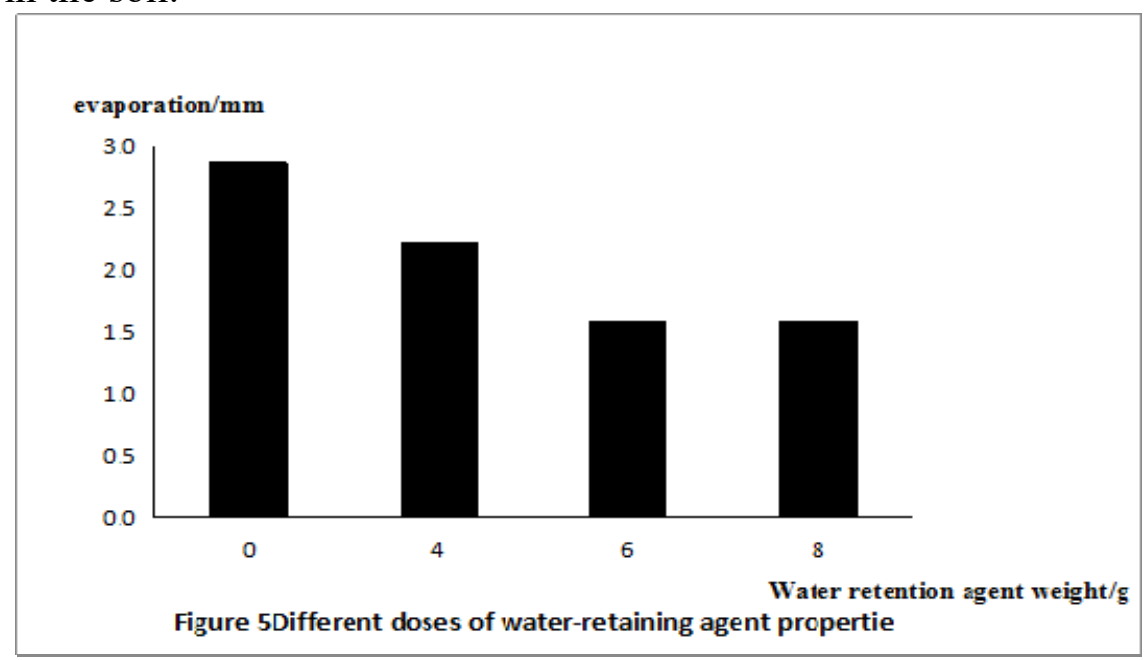

\section{Conclusion}

(1) The results of the test shows that agent can effectively large amounts of water absorption and water retention agent dosage, the greater the water absorbing capacity. Super absorbent polymers can quickly absorb a small amount of water, with the increase of water quantity, bibulous rate is slow. $6 \mathrm{~g}$, $8 \mathrm{~g}$ aquasorb bibulous rate close to but larger than $4 \mathrm{~g}$ water retention agent, visible, absorbs $500 \mathrm{ml}$ water, relative $8 \mathrm{~g}, 6 \mathrm{~g}$ aquasorb aquasorb water absorption efficiency is higher.

(2) After each dose aquasorb added EM bacteria in the soil, can effectively reduce water evaporation, $6 \mathrm{~g}, 8 \mathrm{~g}$ aquasorb same amount of evaporation, we can see beyond a certain dose, the aquasorb same mass of water absorption, water retention in the soil little difference in performance. 


\section{References}

[1] Janardan S, Singh J. Effect of stockosorb polymersand potassium levels on potato and onion[J]. J PotassiumRes, 1998,4(1), p.78_82.

[2] Bowman D C, Evans R Y. Calcium inhibition of polyacrylimidegel hydration is partially reversible by potassium[J]. Hort Sci, 1991,26(8), p.1063_1065.

[3] Liuruifeng, Zhangjunping, Zhengxin, Wangaiqin. PAM-atta Composite Retaining Agent on Soil Physical Properties.Soil, 2006, 38(1), p.86_91

[4] Helalia A, Letey J. Cationic polymer effects on infiltration rates with a rainfall simulator. Soil Science Society of America Journal,1998, 52, p.247_250

[5]Dutaisheng ,Kang shaozhong, Weihua. Aquasorb application in water saving agriculture Situation and Prospects [J]. Research of Agricultural Modernization, 2000,21(5), p.51_54.

[6] Likaiyang,Rentianrui.The application of super absorbent resin in agriculture[J].Journal of process engineering,2002,2(1), p.91_96.

[7] Huangzhanbin,Zhangguozhen,Liyang,etc.Super absorbent polymers characteristics and its application in agriculture[J].Journal of agricultural engineering,2002,18(1), p.22_26.

[8] Liuyingxia,Changxianbo,Yangqixia. EM bacteria to raise the quality of the shrimp ponds effect.Anhui agricultural science, 2010,38 (13).

[9] Zhangjiangang,Wangyong,Wangyouke, etc.10 super absorbent polymers comparative study of the basic characteristics[J].The dry areas of agricultural research, 2009

[10]Jinli,Jiangqiu,Zhanglingxiao.Testing of two retaining agent performance[J].Technology and promotion,2004,(4), p.43_44. 